\title{
Dysphagia to liver failure
}

\author{
Vincent Ting Fung Cheung, ${ }^{1}$ Jey Singanayagam, ${ }^{2}$ Angus Molyneux, ${ }^{3}$ Neil Rajoriya ${ }^{1}$
}

'Department of

Gastroenterology, Milton

Keynes University Hospital,

Milton Keynes, UK

${ }^{2}$ Department of Radiology,

Milton Keynes University

Hospital, Milton Keynes, UK

${ }^{3}$ Department of

Histopathology, Milton Keynes University Hospital, Milton

Keynes, UK

\section{Correspondence to}

Dr Vincent Ting Fung Cheung, vincent.cheung@doctors.org.uk

Accepted 19 September 2015

CrossMark

\section{To cite: Cheung VTF,}

Singanayagam $J$,

Molyneux A, et al. BMJ

Case Rep Published online:

[please include Day Month

Year] doi:10.1136/bcr-2015-

212522

\section{DESCRIPTION}

A 54-year-old man presenting with dysphagia, weight loss, epigastric pain and cervical lymphadenopathy was referred directly to endoscopy. The medical history included hypertension and hypercholesterolaemia. Blood tests showed normal bilirubin, aspartate transaminase (AST) $490 \mathrm{iu} / \mathrm{L}$, $\gamma$-glutamyl transferase (GGT) $535 \mathrm{iu} / \mathrm{L}$, alkaline phosphatase (ALP) $829 \mathrm{iu} / \mathrm{L}$ and prothrombin time (PT) $13 \mathrm{~s}$.

Gastroscopy showed a lower oesophageal lesion (figure 1) with biopsies showing high-grade dysplasia. A CT scan showed lower oesophageal wall thickening and multiple lymphadenopathy in the chest/abdomen but no liver metastases (figure 2). The local multidisciplinary team meeting outcome was for repeat oesophageal biopsies and supraclavicular lymph node biopsy to exclude a lymphoma.

The patient thereafter clinically deteriorated over a 4-week period, developing jaundice. On admission, he became overtly encephalopathic within $48 \mathrm{~h}$, with a suggestion of acute liver failure. Bloods revealed: bilirubin $238 \mu \mathrm{mol} / \mathrm{L}$, AST $1034 \mathrm{iu} / \mathrm{L}$, GGT $569 \mathrm{iu} / \mathrm{L}$, ALP $887 \mathrm{iu} / \mathrm{L}$, albumin $20 \mathrm{~g} / \mathrm{L}, \mathrm{PT} 27.2 \mathrm{~s}$ and lactate $4.7 \mathrm{mmol} / \mathrm{L}$. Repeat imaging showed no signs of liver metastasis and acute liver screen was negative. Repeat oesophageal biopsies showed poorly differentiated adenocarcinoma. The patient rapidly deteriorated and died before a planned liver biopsy could be performed.

Post mortem revealed disseminated oesophageal adenocarcinoma, lymph node metastases, ascites and diffuse liver metastases replacing the majority of the liver parenchyma. The potential short life span of patients with fulminant liver failure means prompt assessment is essential, however the cause can often remain undiagnosed in some patients. There are reports of fulminant liver failure in patients with breast ${ }^{1}$ and lung cancer, ${ }^{2}$ and liver metastases in any cancers can cause deranged liver function tests, but this case highlights a clinical liver failure presentation in oesophageal adenocarcinoma.

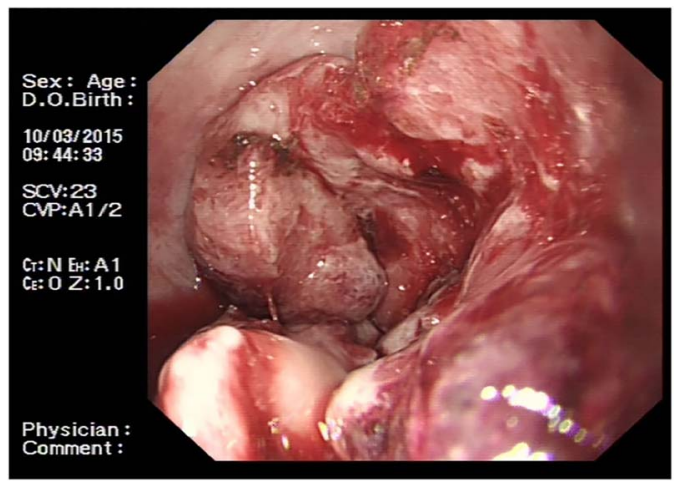

Figure 1 Endoscopic picture of oesophageal tumour.

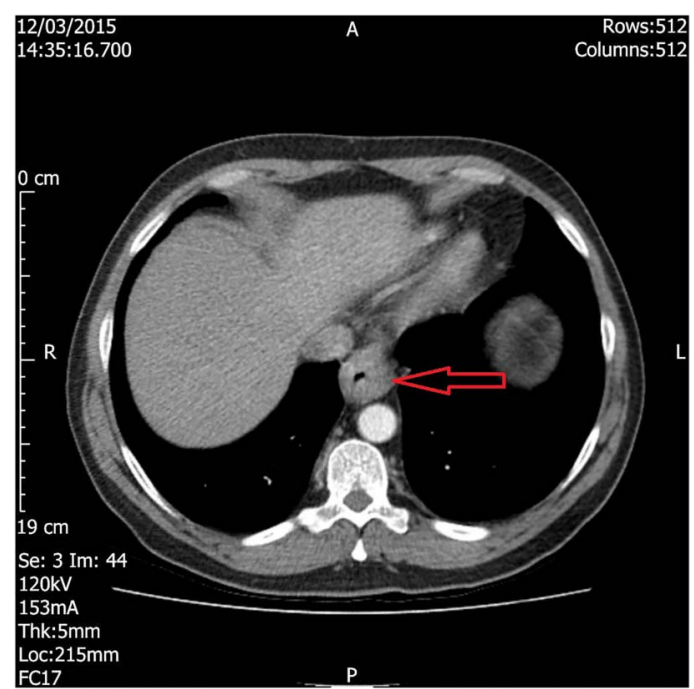

Figure 2 CT scan showing oesophageal cancer (red arrow) but no obvious liver lesions.

\section{Learning points}

- Liver metastases may not be apparent on CT or MRI modalities.

- Diffuse liver metastases can cause liver failure in oesophageal adenocarcinoma and if there is clinical suspicion, a liver biopsy may be helpful.

- While discrete liver metastases are common in different malignancies, diffuse infiltration and parenchymal replacement are relatively uncommon.

Acknowledgements The authors acknowledge Dr Ravi Madhotra (Consultant Gastroenterologist), who initially carried out the endoscopy on the patient and allowed us to use the photos. They also acknowledge Dr Sandro Lanzon-Miller (Consultant Gastroenterologist), who was involved in the care of the patient on the ward.

Contributors VTFC drafted and finalised the manuscript and prepared figure 1. JS prepared the CT image in figure 2. NR and AM contributed to the writing and content of the manuscript.

Competing interests None declared.

Patient consent Obtained.

Provenance and peer review Not commissioned; externally peer reviewed.

\section{REFERENCES}

1 Fadda GM, Santeufemia DA, Cossu-Rocca P, et al. Fulminant liver failure in a patient affected by polycystic liver disease and liver metastases from breast carcinoma. Tumori 2009;95:557-61.

2 Mishima S, Nozaki Y, Mikami S, et al. Diffuse liver metastasis of small-cell lung cancer presenting as acute liver failure and diagnosed by transjugular liver biopsy: a rare case in whom nodular lesions were detected by enhanced CT examination. Case Rep Gastroenterol 2015;9:81-7. 
Copyright 2015 BMJ Publishing Group. All rights reserved. For permission to reuse any of this content visit http://group.bmj.com/group/rights-licensing/permissions.

BMJ Case Report Fellows may re-use this article for personal use and teaching without any further permission.

Become a Fellow of BMJ Case Reports today and you can:

- Submit as many cases as you like

- Enjoy fast sympathetic peer review and rapid publication of accepted articles

- Access all the published articles

- Re-use any of the published material for personal use and teaching without further permission

For information on Institutional Fellowships contact consortiasales@bmjgroup.com

Visit casereports.bmj.com for more articles like this and to become a Fellow 